(C) Inra/Elsevier, Paris

Original article

\title{
Nitrogen fixation by Trifolium repens and Lotus tenuis-based pastures in the Flooding Pampa, Argentina
}

\author{
Roberto Oscar Refia*, César Jorge Escuder ${ }^{b}$ \\ a Facultad de Ciencias Agrarias de la Universidad Nacional de Rosario, Argentina

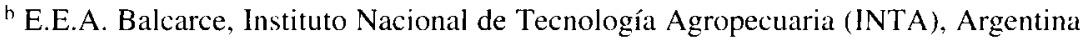

(Received 11 August 1997; accepted 18 June 1998)

\begin{abstract}
An experiment was carried out to estimate $\mathrm{N}_{2}$ fixation of white clover and lotus-based pastures and to study the effects of legumes on two contrasting tall fescue genotypes managed with two continuous grazing intensities on a typical alkaline hydromorphic soil 'Natraquoll'. Binary mixtures of white clover (WC) or lotus (L) and tall fescue temperate (EP) or Mediterranean (MK) were employed. Grazing by steers was applied to maintain two herbage mass levels: 800-1 200 for high level of use (HLU) or $1800-2200 \mathrm{~kg} \mathrm{DM} \cdot \mathrm{ha}^{-1}$ for low level of use (LLU). Measurement of legume cover and nitrogenase activity in sample areas with legumes of the experimental units were carried out ten times in 1986 and eight in 1987. Legume cover was always near $60 \%$ in the samples and varied from 4 to $24 \%$ in the paddocks. $\mathrm{N}_{2}$ fixation was estimated by weighing the nitrogenase activity of samples by legume cover. In 1986 it was: $59 \mathrm{~kg} \mathrm{~N} \cdot \mathrm{ha}^{-1}$ year ${ }^{-1}$ in WC/MK, 52 in WC/EP, 42 in L/MK, 27 in L/EP, 52 in HLU and 39 in LLU, the differences being not significant $(P>0.05)$. In 1987 the values were: $25 \mathrm{~kg} \mathrm{~N} \cdot \mathrm{ha}^{-1} \mathrm{year}^{-1}$ in WC/MK, 14 in WC/EP, 27 in L/MK, 27 in L/EP, 25 in HLU and 21 in LLU. Mixture $\times$ use level interaction was significant (HLU $>$ LLU within L/MK, $P<0.05$ ). Seasonal variations in $\mathrm{N}_{2}$ fixation was observed. Legume content of pastures was the main factor determining $\mathrm{N}_{2}$ fixation. $(\odot$ Inra/ Elsevier, Paris.)
\end{abstract}

$\mathrm{N}_{2}$ fixation / Lotus tenuis / Trifolium repens / Festuca arundinacea / continuous grazing

Résumé - Fixation d'azote par des prairies à base de Trifolium repens ou Lotus tenuis de la Pampa Deprimida en Argentine. Une expérience a été réalisée pour estimer la fixation d'azote par des prairies constituées par du trèfle blanc ou du lotier associé à deux variétés de fétuque élevée ayant des comportements différents et soumises à deux intensités de pâturage continu, sur un sol alcalin hydromorphe typique « Natracuol ». Des mélanges binaires de trèfle blanc (WC) ou de lotier (L) avec la fétuque élevée tempérée (EP) ou méditerranéenne (MK) ont été employés. Les prairies ont été pâturées par des taurillons de manière à maintenir deux niveaux de masse herbacée aérienne : 800-1 $200 \mathrm{~kg}$ MS $\mathrm{ha}^{-1}$ avec la forte intensité de pâturage (HLU) ou 1 800-2 $200 \mathrm{~kg} \mathrm{MS} \cdot \mathrm{ha}^{-1}$ avec la faible intensité de pâturage (LLU). L'activité de la nitrogénase a été estimée pour chaque parcelle pâturée à partir d'échantillons de sol comportant des légumi-

Communicated by Gérard Guyot (Avignon)

* Correspondence and reprints

E-mail: pproper@agatha.unr.edu.ar 
neuses au cours de dix périodes hebdomadaires en 1986 et huit en 1987. La couverture de légumineuses a toujours été proche de $60 \%$ pour les échantillons prélevés et était comprise entre 4 et $24 \%$ pour les parcelles. La fixation de $\mathrm{N}_{2}$ a été estimée en pondérant l'activité de la nitrogénase des parcelles expérimentales par le taux de couverture des légumineuses. En 1986 elle a correspondu à $59 \mathrm{~kg} \mathrm{~N} \cdot h^{-1} \cdot$ année $^{-1}$ pour le mélange WC/MK, 52 pour WC/EP, 42 pour L/MK, 27 pour L/EP, 52 pour HLU et 39 pour LLU, les différences n'étant pas significatives $(P>0,05)$. En 1987 les valeurs obtenues ont été $25 \mathrm{~kg} \mathrm{~N} \cdot \mathrm{ha}^{-1}$.année pour WC/MK, 14 pour WC/EP, 27 pour L/MK, 27 pour L/EP, 25 pour HLU et 21 pour LLU. L'interaction entre mélange et niveau d'utilisation a été significative (HLU $>$ LLU pour L/MK, $p<0,05$ ). Une variation saisonnière de la fixation d'azote a été observée. Le contenu en légumineuses des prairies semble être le principal facteur déterminant de la fixation d'azote. (@ Inra/Elsevier, Paris.)

fixation d'azote / Lotus tenuis / Trifolium repens / Festuca arundinacea / pâturage continu

\section{INTRODUCTION}

The Flooding Pampa is a region of 10 million hectares located in the centre and east portion of the Buenos Aires Province, Argentina, and is the principal cattle breeding area of the country. Its distinctive characteristics are smooth slopes, which had originated from alkaline hydromorphic soils [14], and periodic droughts and floods. Seventy percent of the area is occupied by natural grasslands, which produce about $5500 \mathrm{~kg}$ of $\mathrm{DM} \cdot \mathrm{ha}^{-1}$ year $^{-1}$ [28], with its highest seasonal growth in spring and early summer. Beef production of the region is low and was estimated by Bochetto [3] as $70 \mathrm{~kg} \mathrm{ha}^{-1}$ year $^{-1}$.

Cauhépé et al. [6], proposed to increase beef production by complementing rangeland with sown fertilized pastures. However, the persistence of sown pasture is frequently reduced by various factors: low soil phosphorous levels, poor legume nodulation, the choice of inappropriate plant genotype, ignorance of suitable management practices and climatic adversities [11,21].

An important component of pasture decline is changes in the $\mathrm{N}$ cycle, because the decrease of sown legumes also diminishes $\mathrm{N}$ symbiotic input [13]. This weakens the sown grasses and impairs them when compared to native species, which have a lower $N$ requirement [11]. In addition, $N$ losses by $\mathrm{NH}_{3}$ volatilization from urine patches may be as high as $50 \%$ in alkaline soils of the region [33]. Consequently, it was considered necessary to know how legume species and management affect persistence and $\mathrm{N}_{2}$ fixation.

An interdisciplinary study on structure and functioning of four forage mixtures of tall fescue (Festuca-arundinacea Schreb.) and white clover (Trifolium repens L.) or narrow leaf birdsfoot trefoil (Lotus tenuis Waldst et Kit, common name: lotus), under continuous cattle grazing was carried out in Balcarce. Promising germplasm for the Flooding Pampa obtained from cutting experiments was employed. Continuous grazing was applied because it is the usual system used in the region [3].

The objectives of this study were: a) to estimate $\mathrm{N}_{2}$ fixation of white clover and lotus in sown pastures on a Typic Natraquoll soil in the Flooding Pampa; and b) to study the effects of legume association with two contrasting tall fescue genotypes and of two continuous grazing intensities on $\mathrm{N}_{2}$ fixation.

\section{MATERIALS AND METHODS}

\subsection{Experimental site}

The experiment was carried out at the Balcarce Agricultural Experimental Station, Instituto Nacional de Tecnología Agropecuaria (INTA), Argentina ( $37^{\circ} 45^{\prime} \mathrm{S}$, $58^{\circ} 18^{\prime} \mathrm{W}, 97 \mathrm{~m}$ o.s.l.), on a Typic Natraquoll soil which showed $0.28 \%$ of total $\mathrm{N}$ (equivalent to $3750 \mathrm{~kg}$ of $\left.\mathrm{N} \cdot \mathrm{a}^{-1}\right), 5.3 \%$ of organic matter, C:N ratio of $11: 1$, 
12-23 ppm of plant-available $\mathrm{P}$ and a $\mathrm{pH}$ of $6.6-8.7$ in the $0-11 \mathrm{~cm}$ layer. At depth the $\mathrm{pH}$ rises to 9.5 by $\mathrm{Na}$ content and the B horizon is textural, factors which lead to poor drainage.

The climate is humid-temperate ( $\mathrm{Cfb}$ of Koppen system), with $937 \mathrm{~mm}$ of annual rainfall evenly distributed and mean monthly temperatures between $7.6{ }^{\circ} \mathrm{C}$ (July) and $19.7{ }^{\circ} \mathrm{C}$ (January). Frost is normally registered on 77 days of the year, $95 \%$ of which occur between May and October.

\subsection{Pastures and grazing management}

In the fall of 1984 binary mixtures of Trifolium repens cv. El Lucero (WC) or Lotus tenuis population Monte (L.) and Festuca arundinacea cv. El Palenque (EP) or Maris Kasba (MK) were sown. The annual growth distribution is concentrated in autumnwinter-spring in WC and MK and spring-summerautumn in $L$ and EP. Sowing was carried out on lines $15 \mathrm{~cm}$ apart, employing $10 \mathrm{~kg}$ of seed $\cdot \mathrm{ha}^{-1}$ of $\mathrm{MK}$ or $\mathrm{EP}, 3 \mathrm{~kg} \cdot \mathrm{ha}^{-1}$ of $\mathrm{L}$ and $1.5 \mathrm{~kg} \cdot \mathrm{ha}^{-1}$ of WC. This legume was inoculated with A-12 genotype of Rhizobium trifolii, obtained in Balcarce through a local isolation selection. L was inoculated with local non-selected isolation of $R$. loti.

In autumn 1985, two continuous grazing intensities, defined by the maintenance of herbage mass in a steady state into the rank 800-1 $200 \mathrm{~kg} \mathrm{DM} \cdot \mathrm{ha}^{-1}$ for the 'high level of use' treatment (HLU) and $1800-2200 \mathrm{~kg} \mathrm{DM} \cdot \mathrm{ha}^{-1}$ for the 'low level of use' (LLU) were applied [2]. Grazing by steers using a variable stocking rate to compensate seasonal plant growth changes was carried out.

At the onset of the experiment, the pastures were 19 months old and the seeded components constituted more than $90 \%$ of the existing biomass.

\subsection{Experimental design and data analysis}

A split-plot design with subunits arranged in strips which were duplicated was employed [7]. Within each replicate, the four mixtures were allocated to four 1 ha main plots, and then two strips (HLU and LLU) were established, resulting in eight 0.5 ha subunit of mixture $x$ use level combinations. The subunit arrangement was due to operative difficulties of pasture sowing and animal distribution.
Analysis of variance was carried out using the model:

$$
Y_{i j k}=\mu+R_{i}+\alpha_{j}+\varepsilon_{i j}+B_{k}+\varepsilon_{i k}+\tau_{j k}+\varepsilon_{i j k}
$$

where the value of an observation ( $\mathrm{Y}$ ) is the result of the effects of general means $(\mu)$, repetition $(R)$, forage mixture $(\alpha)$, level of use $(\beta)$, mixture $\times$ use level interaction $(\tau)$ and random associated components $(\varepsilon)$.

The design employed was split again (resulting in a split-split plot with a strip design) to include time of the year as a third factor and to analyse time $\times$ mixture and time $\times$ use level interactions. Previously, absence of correlation between observations within a plot across time and matrix homogeneity of population covariances were tested [34].

The means were compared by Tukey's test.

\subsection{Measurements and estimations}

Nitrogenase activity of the pastures was measured in ten weekly periods during 1986 and eight in 1987 , distributed nearly uniformly throughout the year. Acetylene reduction technique on pasture samples and soil mass was employed. Samples were obtained with the methodology described by Hoglund and Brock [15] modified locally [26], which uses composite samples integrated by pasture and soil cores $2.5 \mathrm{~cm}$ in diameter. Because of the low legume content of the experimental pastures, core sampling was carried out where legumes were present along transects randomly placed. Composite samples were integrated by 20 cores and on average had $94 \mathrm{~cm}^{2}$ pasture surface by $11 \mathrm{~cm}$ soil depth. Six composite samples were drawn from each experimental unit ( $0.5 \mathrm{ha})$ and nitrogenase activity was averaged. Incubation with acetylene was carried out in situ in $2.33 \mathrm{~L}$ white polyethylene vessels placed on the soil in the shade for $1 \mathrm{~h}$ between $10.30 \mathrm{a} . \mathrm{m}$. and $1.00 \mathrm{p} . \mathrm{m}$. Simultaneously edaphic moisture in $0-10 \mathrm{~cm}$ soil layer and air temperature $10 \mathrm{~cm}$ from ground level were registered. To measure the ethylene produced, $10 \mathrm{cc}$ gas samples were analysed by gas chromatography in the laboratory.

Legume cover of the samples was $59.5 \% \pm 2.4(x \pm \mathrm{SE})$. To relate nitrogenase activity to area units it was weighed by treatment legume cover. This was estimated by visual projection of 500 points $20 \mathrm{~cm}$ apart along two randomized transects in each experimental unit. In addition, to describe the pastures, biomass legume percentage of treatments was measured with destructive sampling using a $20 \times 20 \mathrm{~cm}$ frame. 
Theoretical nitrogen fixation of the mixtures and levels of use were estimated using nitrogenase activity and legume cover data. Legume cover value of the samples was assumed to be $60 \%$ and activity was referred to 1 ha and $24 \mathrm{~h}$. Conversion of ethylene produced to $\mathrm{N}$ theoretically fixed was carried out by means of $3: 1$ ratio, which would be suitable for pastures under moderate to intensive grazing [8]. These procedures are synthesized in the following expression:

$$
\mathrm{NTF}_{\mathrm{U}}=3.9716 \times \mathrm{EHP}_{\mathrm{U}} \times \mathrm{COV}_{\mathrm{U}}
$$

where $\mathrm{NTF}^{\mathrm{U}}$ is theoretical $\mathrm{N}$, fixation of experimental unit in $\mathrm{gN}$ (ha $\times$ day $)^{-1} ; 3.971 \overline{6}$ is the combined factor of transformations in $\mathrm{gN} \times$ hour $\times$ sample (ha $x$ day $x$ $\mu \mathrm{mol} \times \%)^{-1}$; $\mathrm{EHPU}^{\mathrm{U}}$ is the ethylene hour production of experimental unit, average of six samples in $0.5 \mathrm{ha}$, in $\mu$ mol (sample $\times h)^{-1} ; \mathrm{COV}_{U}$ is the legume sown cover $(\%)$ in the experimental unit.

The herbage mass was measured monthly by destructive sampling and weekly by visual estimates of sward height. On the basis of this information, stocking rate changes were carried out.

\section{RESULTS}

\subsection{Pasture evolution}

Meteorological conditions during 1986 and 1987 in the experimental area are shown in table $I$.

Summer balance between rainfall and evapotranspiration was $-109 \mathrm{~mm}$ in 1986 versus $-159 \mathrm{~mm}$ in 1987, but water stress in the second summer was still more accentuated because spring balance was $-5 \mathrm{~mm}$ in 1986 versus $+143 \mathrm{~mm}$ in 1985 .

On an annual average, herbage mass removed by clipping was maintained at $1319 \pm 71 \mathrm{~kg} \mathrm{DM} \cdot \mathrm{ha}^{-1}$ for HLU $\left(x \pm\right.$ SE) and $2243 \pm 107 \mathrm{~kg} \mathrm{DM} \cdot \mathrm{ha}^{-1}$ for LLU, the difference was significant $(P<0.05)$. Frequent changes of stocking rate controlled pasture growth and maintained treatment differences throughout the year (table II).

Legume percentage of both legumes in herbage mass was reduced. The 1986 annual average content of WC in WC/EP was $6.0 \pm 1 \%$ and

Table I. Monthly values of mean air temperature $\left({ }^{\circ} \mathrm{C}\right)$, precipitation $(\mathrm{mm})$ and climatic potential cvapotranspiration by Penman $(\mathrm{mm})$ at Balcarce during the experimental period.

\begin{tabular}{lrrrrrrrrrrrr}
\hline Month & $\mathrm{J}$ & $\mathrm{F}$ & $\mathrm{M}$ & $\mathrm{A}$ & $\mathrm{M}$ & $\mathrm{J}$ & $\mathrm{J}$ & $\mathrm{A}$ & $\mathrm{S}$ & $\mathrm{O}$ & $\mathrm{N}$ & $\mathrm{D}$ \\
\hline $\begin{array}{l}\text { Temperature } \\
\quad 1986\end{array}$ & 20 & 19 & 16 & 14 & 10 & 8 & 8 & 8 & 11 & 12 & 15 & 18 \\
$\quad 1987$ & 22 & 23 & 19 & 15 & 8 & 8 & 8 & 8 & 9 & 12 & 17 & 18 \\
& & & & & & & & & & & & \\
$\begin{array}{l}\text { Precipitation } \\
\quad 1986\end{array}$ & 92 & 61 & 89 & 129 & 28 & 36 & 12 & 41 & 73 & 93 & 163 & 42 \\
$\quad 1987$ & 68 & 67 & 78 & 26 & 169 & 12 & 119 & 36 & 32 & 143 & 37 & 173 \\
Evapotransp. & & & & & & & & & & & & \\
$\quad(1981-1990)$ & 138 & 125 & 78 & 48 & 27 & 16 & 20 & 30 & 51 & 67 & 97 & 138 \\
\hline
\end{tabular}

Table II. Herbage mass ( $\mathrm{kg}$ DM.hat ${ }^{-1}$ ): three monthy and experimental period means of HLU and LLU. Letters show significant differences between means by Tukey test $(P<0.05)$.

\begin{tabular}{rrrrrrrrrr} 
& JFM & AMJ & JAS & OND & JFM & AMJ & JAS & OND & Means \\
\hline HLU & 1457 & 997 & 951 & 1416 & 1305 & 1307 & 1092 & 2025 & $1319^{\mathrm{b}}$ \\
LLU & 3251 & 2143 & 1716 & 2290 & 2057 & 1849 & 1737 & 2902 & $2243^{\mathrm{a}}$ \\
\hline
\end{tabular}


Table III. Legume cover (\%): annual mean and standard error for distinct factors and levels.

\begin{tabular}{lcc}
\hline Factor or level & 1986 & 1987 \\
\hline WC/EP & $14.7 \pm 1.1$ & $6.7 \pm 0.6$ \\
WC/MK & $18.7 \pm 1.0$ & $11.7 \pm 0.7$ \\
L/EP & $11.6 \pm 0.5$ & $13.4 \pm 0.9$ \\
L/MK & $17.5 \pm 1.0$ & $14.1 \pm 1.0$ \\
HLU & $16.0 \pm 0.8$ & $12.2 \pm 0.6$ \\
LLU & $15.3 \pm 0.6$ & $10.7 \pm 0.7$ \\
\hline
\end{tabular}

within WC/MK $6.3 \pm 0.7 \%$. L content was $6.7 \pm 0.9 \%$ in $\mathrm{L} / \mathrm{EP}$ and $14.2 \pm 2.2 \%$ in L/MK. HLU showed $8.6 \pm 1.1 \%$ of legumes and LLU $8.0 \pm 1 \%$. In 1987 the values were on average $27 \%$ lower. WC content was minimal in summer ( $1 \%$ in $\mathrm{WC} / \mathrm{EP})$ and maximal in spring ( $12 \%$ in WC/MK), while $\mathrm{L}$ content was minimal in winter $(5 \%$ in $\mathrm{L} / \mathrm{EP})$ and maximal in summer $(36 \%$ in L/MK).

Due to reduced legume percentage contents, cover values were low (table III).

The cover of both legumes tended to be higher in mixture with $\mathrm{MK}$ and in HLU (figure I), the differences being significant $(P<0.05)$ only in the

\section{a) Legume cover: mixtures.}

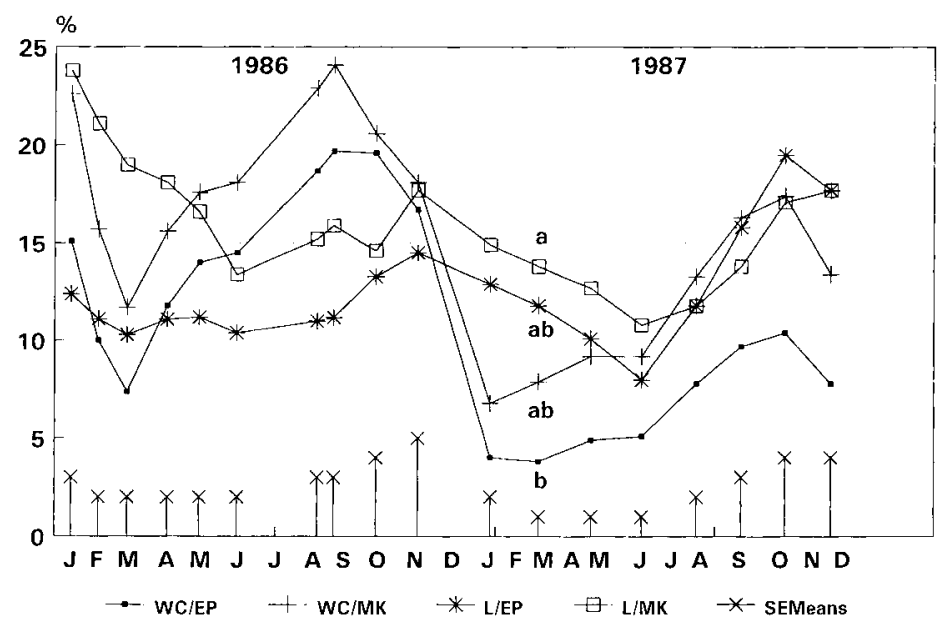

Figure 1. Evolution of legume cover in the mixtures (a) and in the levels of use (b). The letters show significant differences between means by Tukey test $(P<0.05)$. b) Legume cover: levels of use.

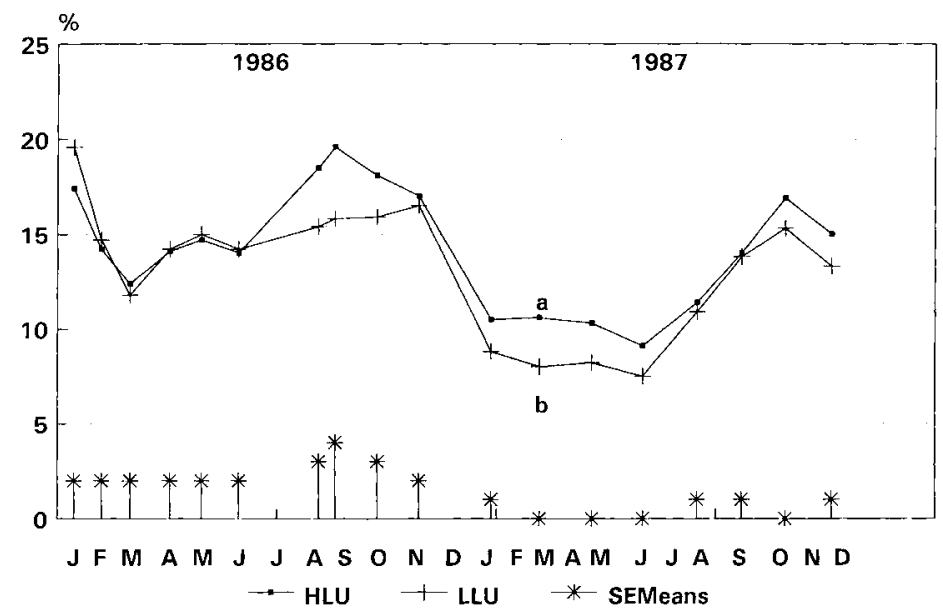


Table IV. Mixture $\times$ level of use interactions.

a) Interactions in legume cover. Figures are $\%$ of legume cover.

Letters compare mixtures within the levels of use (by Tukey, $P<0.05$ ).

\begin{tabular}{lccc}
\hline Level of use & Mixture & October 1987 & December 1987 \\
\hline HLU & WC/EP & $12.4^{\mathrm{b}}$ & $9.8^{\mathrm{b}}$ \\
& WC/MK & $17.5^{\mathrm{ab}}$ & $14.1^{\mathrm{ab}}$ \\
& L/EP & $16.4^{\mathrm{ab}}$ & $15.0^{\mathrm{ab}}$ \\
L/MK & $21.1^{\mathrm{ab}}$ & $21.3^{\mathrm{a}}$ \\
LLU & WC/EP & $8.3^{\mathrm{b}}$ & $5.8^{\mathrm{b}}$ \\
& WC/MK & $17.3^{\mathrm{ab}}$ & $12.8^{\mathrm{ab}}$ \\
& L/EP & $22.7^{\mathrm{ab}}$ & $20.4^{\mathrm{al}}$ \\
& L/MK & $13.0^{\mathrm{ab}}$ & $14.2^{\mathrm{ab}}$
\end{tabular}

b) Interactions in nitrogenase activity. Figures are mols of ethylene/(sample $\times$ hour).

Letters compare levels of use within the mixtures (by Tukey, $P<0.5$ ).

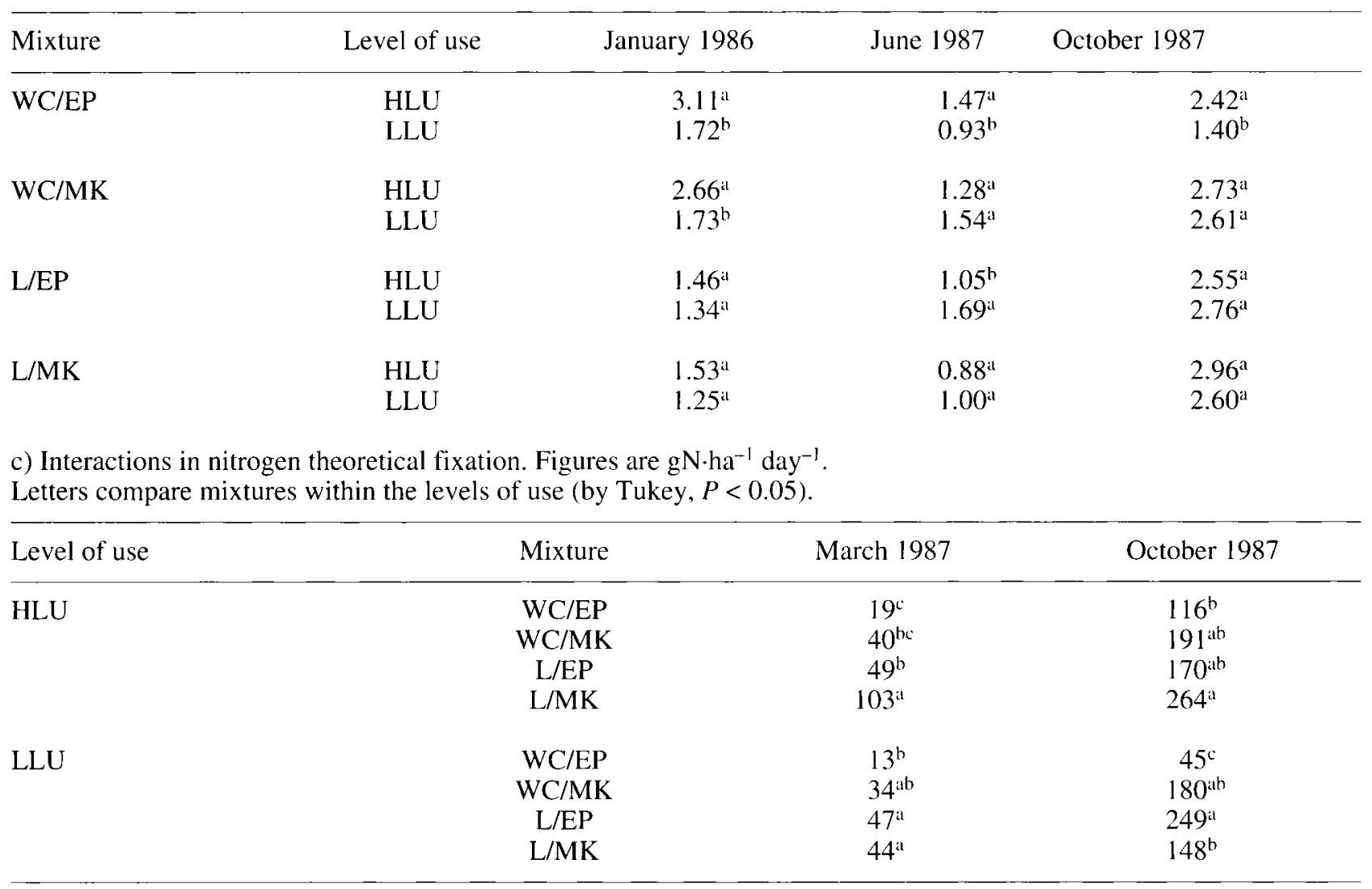

summer of the second year. In the following spring, significant mixture $\times$ use level interaction was found $(P<0.05)$, showing WC/EP lower legume cover than L/EP in LLU and L/MK in HLU.
Likewise, L/MK was higher in HLU than in LLU (table IVa).

During the whole experiment, a mixture $\times$ date interaction was observed $(P<0.01)$. During the 
first year the cover of $\mathrm{L}$ appeared stable in both mixtures, while WC cover with both grasses decreased in summer (March) and was maximal in late winter (September, $P<0.01$ ). This pattern was repeated for $\mathrm{WC}$ in the second year, whereas in $\mathrm{L}$ seasonal differences appeared in L/EP, between a minimum in late autumn (June) and a maximum in spring (October, $P<0.05$ ).

\subsection{Nitrogenase activity}

Figure 2 shows nitrogenase activity measured during 1986 and 1987. Mean values of $10 \mathrm{~cm}$ air temperature and $0-10 \mathrm{~cm}$ soil layer moisture during the measurement periods are also shown.

The mean coefficients of variation of activity measured for the whole experimental period were: $23.2,24.5$ and $21.4 \%$ for forage mixture, level of use and interactive effects, respectively. In summer 1986 mixture $\times$ level of use interaction was significant $(P<0.05)$, because activity within WC pastures was greater in HLU than in LLU, whereas in $\mathrm{L}$ pastures both levels were similar (table $\mathrm{IVb}$ ). During the second year WC/EP output had similar results in late autumn and spring $(P<0.05)$. Likewise, WC/EP within LLU had lower activity than other mixtures (table $I V b$ ).

\section{a) Nitrogenase activity: legume base.}

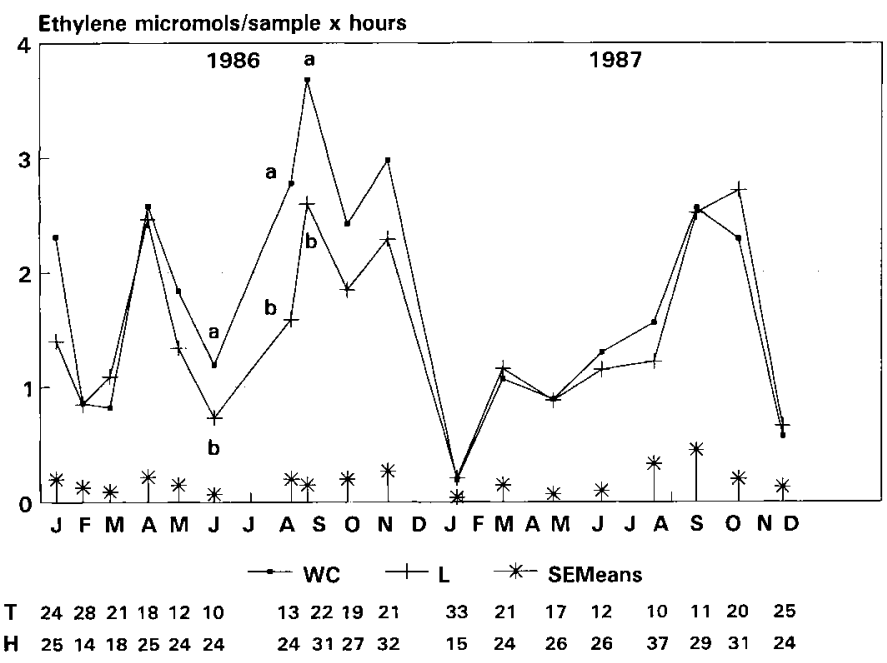

b) Nitrogenase activity: levels of use.

Figure 2. Evolution of nitrogenase activity in both legumes (a) and in the levels of use (b). Letters show significant differences between means by Tukey test $(P<0.05)$. T: air temperature $\left({ }^{\circ} \mathrm{C}\right)$ at $10 \mathrm{~cm}$ over the soil. $\mathrm{H}$ : soil moisture $(\%)$ in $0-10 \mathrm{~cm}$ layer.

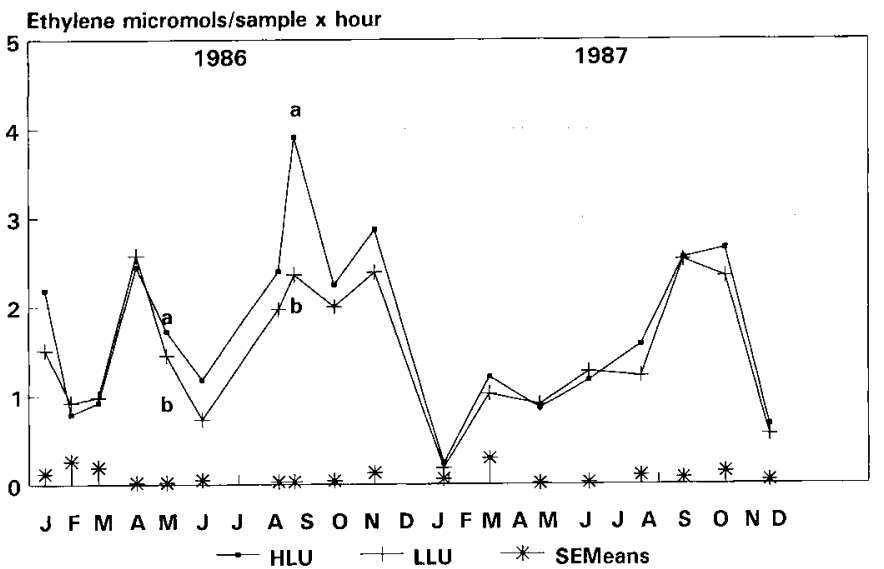


In the first year mixture $x$ date and use level $x$ date interactions were found (for both, $P<0.01$ ). In both WC mixtures nitrogenase activity had a summer minimal value (February, March) and another autumn value (June), statistically lower $(P<0.05)$ than the values observed in April, winter and spring in WC/EP and in January, April and October in WC/MK. Instead, the $\mathrm{L}$ mixture activity was uniform during long periods $(P>0.05)$, with maxima $(P<0.05)$ in January, April and September in L/EP and in April, September and November in $\mathrm{L} / \mathrm{MK}$ (figure 2).

Within HLU minimal nitrogenase activity was registered in summer (February, March) and late autumn (June), and one absolute maximum was found in late winter (September, $P<0.05$ ), while in LLU all summer-autumn values (except April) were lower than those found in winter-spring $(P<0.05)$.

During the second year, only date had a global effect $(P<0.01)$, showing a maximum of nitrogenase activity in late winter and early spring (September-October) from a minimum observed in early summer (January).

\subsection{Theoretical nitrogen fixation}

Figure 3 shows the estimated values of $\mathrm{N}_{2}$ fixation for the different mixtures maintained under the two grazing levels.

When cover and nitrogenase activity data were combined to estimate theoretical fixation of $\mathrm{N}_{2}$ the variation coefficients increased, averaging: 53,37 and $36 \%$ for mixture, use level and its interaction effects, respectively. WC/MK was higher than the other mixtures in the first summer $(P<0.05)$. No effects of the level of utilization or mixture $\times$ utilization level were significant during the first year.

In the second year only some interactions were observed (table $I V c$ ). L/MK was the mixture that showed the best performance, exceeding both WC mixtures at HLU in summer $(P<0.05)$, and WC/EP in spring; and within LLU was also higher than WC/EP in summer $(P<0.05)$. On the other hand, L/EP in LLU would be fixing more $\mathrm{N}_{2}$ than
WC/EP in summer and spring $(P<0.05)$. Likewise, HLU showed higher theoretical fixation than LLU in L/MK (summer and spring) and WC/EP (spring) $(P<0.05)$.

Overall, during the first year, significant interactions of time $x$ mixture or level of utilization were found $(P<0.01)$. In both WC mixtures the minimum values found in February and March (summer) were different from the maximum in August and September (winter, $P<0.05$ ). $\mathrm{N}_{2}$ fixation in $\mathrm{L} / \mathrm{EP}$ and $\mathrm{L} / \mathrm{MK}$ did not show statistical differences during the year (figure 3).

Within LLU, values of theoretical nitrogen fixation were surpassed only in November by the minimum found in June $(P<0.05)$, while in HLU the September maximum was different from the other dates $(P<0.05)$ and in general winter and spring values were higher than summer-autumn values $(P<0.05)$.

In the second year an interaction between mixture and level of utilization was significant $(P<0.05)$, because HLU and LLU differed within L/MK (annual means were $107 \mathrm{~g} \mathrm{~N} \cdot \mathrm{ha}^{-1} \mathrm{~d}^{-1}$ versus $51)$. Temporal variations were also found $(P<0.01)$, showing minimal fixation in January (summer, $8 \mathrm{~g}$ $\mathrm{N} \cdot \mathrm{ha}^{-1} \mathrm{~d}^{-1}$ ) and maximal in September and October (late winter and spring $148 \mathrm{~g} \mathrm{~N} \cdot \mathrm{ha}^{-1} \mathrm{~d}^{-1}$, respectively).

The theoretical annual $N_{2}$ fixation in 1986 was calculated by integration of estimates, being $(x \pm \mathrm{SE}): 52 \pm 10 \mathrm{~kg}$ of $\mathrm{N} \cdot \mathrm{ha}^{-1} \times$ year for WC/EP, $59 \pm 9$ for $\mathrm{WC} / \mathrm{MK}, 27 \pm 2$ for L/EP, $42 \pm 7$ for L/MK, $52 \pm 9$ for HLU and $39 \pm 3$ for LLU. The differences found were not significant.

Values for 1987 were lower, being $14 \pm 4 \mathrm{~kg}$ $\mathrm{N} \cdot \mathrm{ha}^{-1} \times$ year for WC/EP, $25 \pm 1$ for WC/MK, $27 \pm 4$ for $\mathrm{L} / \mathrm{EP}, 27 \pm 7$ for $\mathrm{L} / \mathrm{MK}, 25 \pm 5$ for $\mathrm{HLU}$ and $21 \pm 5$ for LLU. This year the mixture $\times$ use level interaction was significant $(P<0.05)$, because L/MK showed a higher theoretical $\mathrm{N}_{2}$ fixation in HLU than LLU (37 versus $18 \mathrm{~kg} \mathrm{~N} \cdot \mathrm{ha}^{-1^{-}} \times$year).

Taking both years into consideration, in WC pastures $27 \%$ of $\mathrm{N}_{2}$ fixation occurred in summerautumn and $73 \%$ in winter-spring, whereas in $\mathrm{L}$ pastures the corresponding distribution was of 35 and $65 \%$, respectively. 


\section{a) Theoretical $\mathrm{N}_{2}$ fixation: mixtures.}



b) Theoretical $\mathrm{N}_{2}$ fixation: levels of use.

Figure 3. Evolution of $\mathrm{N}_{2}$ fixation estimations in the mixtures (a) and in the levels of use (b). The differences between means are not significative within each date $(P>0.05$, by Tukey).

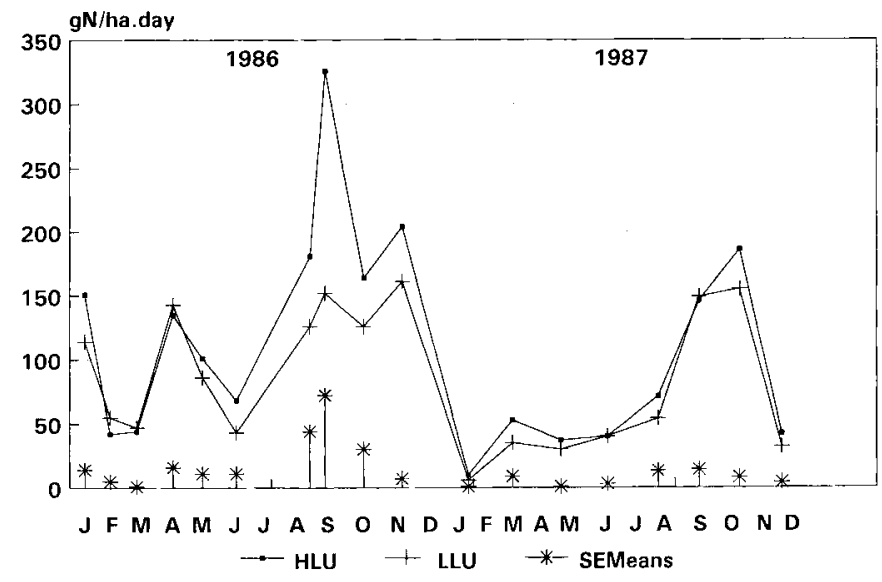

\section{DISCUSSION}

\subsection{Legume content of pastures}

The reduced percentage content of WC in these pastures, lower than $10 \%$ throughout almost all the experimental period contrasted with the values usually found in temperate regions of the Northern hemisphere, Australia or New Zealand. The low content of WC in this experiment would be associated with the reduction of legume content frequently observed in sown pastures in temperate areas of South America during the first years of utilization [11].

The effect of different mixtures and grazing managements on the content of Lotus tenuis has been little studied $[22,23]$. The values found here showed a summer maximum and similar content to that observed in white clover during the rest of the year.

Legume cover (figure l) reflected approximately the reduced biomass values. WC cover showed greater oscillations than $\mathrm{L}$, suggesting that this species is more sensitive to environmental conditions. On the contrary, L cover exhibited an appreciable stability during the summer drought conditions. This tolerance to water stress could be one of the causes for the success of the propagation of the species in the Flooding Pampa. 
In both legumes high covering tendencies in association with MK and LLU point out the importance of grass competition control in mixtures with tall fescue. In our research conditions, without nitrogen fertilization, MK showed thinner tillers, lower height and spring growth rates and greater acceptability by the ruminants than EP $[12,20]$. These characteristics could favour white clover growth owing to lesser grass competition. Likewise, MK showed greater time complementarity with $\mathrm{L}$ than with $\mathrm{WC}$, because besides the mentioned characteristics, MK summer growth stopped completely, which in a typical year could happen from mid December to mid March [20]. Finally, increasing defoliation intensity (HLU versus LLU) could promote the development of creeping (WC) or prostrated (L) legumes, both very sensitive to light competition.

\subsection{Nitrogenase activity}

The high and relatively constant legume cover of the pasture samples observed allows the use of the nitrogenase activity measurements as an index of $\mathrm{N}_{2}$ fixation of the pastures, independently of legume content. This index is similar to the concept of specific acetylene reducing activity (specific A.R.A.) of Vessey and Patriquin [32].

The annual evolution of WC nitrogenase activity (figure 2) was similar to that described for this species by other researchers of the Southern hemisphere [15]. The activity was higher during favourable conditions of humidity, temperature or irradiation for vegetative growth $[5,16]$, while the minima can be related to water stress [1] or reduced levels of irradiation and temperature $[19,25]$ The activity drops in spring with the onset of reproductive state in WC [19] and with a gradual increase in evapotranspiration.

$\mathrm{L}$ activity evolved in a similar way, indicating that both species could respond in a similar way to environmental or phenological restrictions.

WC nitrogenase activity was higher than that of $\mathrm{L}$ during most part of the first year (significantly or as a trend, figure 2). This could have been due to differences in the degree of breeding of both species and its microsymbionts. However, L activity seemed to be more stable during dry periods and would be an adaptative advantage because water stress is a frequent restriction in the Flooding Pampa.

The greater activity found in HLU compared to that of LLU in May and September could be associated with a better light environment. Legumes developed a low and dense canopy in HLU, it being unlikely that energy capture was restricted with an herbage mass near to $1000 \mathrm{~kg}$ of DM ha ${ }^{-1}$ [18]. In summer, the reproductive state in WC was reduced by HLU to a greater extent than that observed in $\mathrm{L}$, and this difference could explain the mixture $x$ level of use interaction.

During the dry environmental conditions of the second year (table I), WC cover was reduced drastically (figure 1 ) and the nitrogenase activity of both legumes decreased (figure 2). The greater sensitivity of WC compared with that of $L$ to environmental changes would reduce the differences found during the first year. The absence of any effects of level of use shows the secondary roll of grazing management when compared with meteorological conditions, although sometimes LLU had a negative effect on WC activity in WC/EP, possibly due to poor grass competition control.

\subsection{Nitrogen fixation calculations}

The high variability resulting from combined cover and nitrogenase activity data could be the cause for the absence of significant differences between mixtures or levels of use (figure 3).

Although theoretical seasonal $\mathrm{N}_{2}$ fixation results from both legume cover and nitrogenase activity, the shape of the curves (figure 3) denotes that the second variable has a greater weight.

The annual evolution of $\mathrm{N}_{2}$ fixation in WC pastures was similar to that found under continuous grazing in other temperate regions of the world [5], reaching a maximum with favourable conditions for plant growth and a minimum during water 
stress, low temperatures or reduced photoperiod. No information on seasonal variation or levels of $\mathrm{N}_{2}$ fixation of Lotus tenuis pastures are available.

The amounts of nitrogen fixation estimated here were lower than those usually found in white clover or Lotus corniculatus-based pastures. The main determinants of this result could be adverse edaphic characteristics, the continuous grazing and low legume content of the pastures.

The detrimental effect of edaphic characteristics was hypothesized at the onset of this work. The amount of mineral $\mathrm{N}$ of the upper horizon could be an important issue to be considered because of its high total $\mathrm{N}$ content. The depressor effect of mineral $\mathrm{N}$ on symbiotic $\mathrm{N}$ fixation of white clover is extensively documented [1]. Subsuperficially $\mathrm{pH}$ increases and anaerobiosis could also be a harmful factor [4]. In the pastures with $\mathrm{pH}$ gradients of upper soil between 6.6 and $8.7 \mathrm{WC}$ content was greatly reduced although this decrease was not significant. On the other hand, $L$ became dominant showing its tolerance to alkaline $\mathrm{pH}$ [24]. The content of assimilable $P$ was adequate for both legumes $[10,24]$.

Harmful effect of continuous grazing is unlikely at least for WC. The effect of continuous grazing on $\mathrm{N}_{2}$ fixation by this species has been considered either adverse [19] or beneficial [5]. The trend towards greater $\mathrm{N}_{2}$ fixation in HLU is in agreement with the response found in white clover/perennial rye grass pastures as the intensity of grazing [30] or cutting $[18,29]$ increased.

There are no reports on the effects of different grazing intensities on $\mathrm{N}_{2}$ fixation of Lotus tenuis. In this experiment, both intensities of continuous grazing did not affect the growing point density of this species [23], although apparently the number and size of plants varied in compensatory form from the first to second summer, suggesting plasticity according to level of use.

The amounts of $\mathrm{N}_{2}$ fixation found in other temperate regions are higher than those estimated here and were measured in pastures with greater legume content. For instance, in a series of trials carried out in New Zealand on pastures with an average legume biomass content of $27.1 \%$, white clover fixed $185 \mathrm{~kg} \mathrm{~N} \cdot \mathrm{ha}^{-1}$ year $^{-1}$ [16]. Lambert [17], in ranges intercropped with white, red and subterranean clover and Lotus pedunculatus found annual amounts of 105,129 and $224 \mathrm{~kg} \mathrm{~N} \cdot \mathrm{ha}^{-1}$ with 14.8 , 14.7 and $21.5 \%$ of legumes under continuous or rotational grazing with sheep and rotationally grazing with cattle, respectively. In pastures with low white clover content under cattle rotational grazing, Crush et al. [9] detected an annual fixation of $97 \mathrm{~kg} \mathrm{~N} \cdot \mathrm{ha}^{-1}$ with $11 \%$ legumes and $60 \mathrm{~kg} \mathrm{~N} \cdot \mathrm{ha}^{-1}$ with $6 \%$ legume content.

It seems that the levels of nitrogenase activity measured in this work were not far from those found in other temperate regions. Legume content was the most important factor in the amounts of the $\mathrm{N}_{2}$ fixation obtained. According to this, edaphic and grazing factors could have scarce incidence on $\mathrm{N}_{2}$ fixation at the physiological level but could be controlling legume content of pastures and therefore the $\mathrm{N}_{2}$ fixation per hectare. For instance, the legumes would only occupy favourable microsites [31] while light grazing during establishment could promote grass dominance.

The degree of current interference of the companion grasses could also be controlling the legume content. The tendency for greater $\mathrm{N}_{2}$ fixation in L/MK and WC/MK compared with the EP mixtures is a reflection of a similar tendency in both legume covers in association with $\mathrm{MK}$, possibly due to better complementation between the growth cycles or to lower aggressiveness of the grass. Furthermore a limited physiological effect is also possible, such as a very intense differential competition by nutrients sometime during the year, because changes in $\mathrm{N}_{2}$ fixation such as those observed between August and September of the first year are based on a very different behaviour of nitrogenase activity between EP and MK mixtures.

Although the $\mathrm{N}_{2}$ fixation levels estimated in this work are small, impact on the forage production of Flooding Pampa may be substantial. Currently, with the exception of the area where Lotus tenuis is naturally disseminated, the scarcity of legumes in the ranges and the economic difficulties for nitrogen fertilization suggest that the volume of $\mathrm{N}$ cycling is reduced. An annual input of $10-15 \mathrm{~kg}$ of 
$\mathrm{N} \cdot \mathrm{ha}^{-1}$ onto ranges coming from rains and $\mathrm{N}_{2}$ fixation is expected [27]. This input would be in dynamic equilibrium with the amount of $\mathrm{N}$ exported in cattle meat and volatilized from urine and faeces, taking into account that the regional animal production is low. The introduction of Lotus tenuis or white clover adapted germplasm could substantially modify the volume of $\mathrm{N}$ cycling and animal production [26].

\section{CONCLUSIONS}

The amounts of $\mathrm{N}_{2}$ fixation estimated in this work in white clover and lotus-based pastures on Typic Natraquoll soil were reduced, with means no higher than $60 \mathrm{~kg} \mathrm{~N} \cdot \mathrm{ha}^{-1}$ year $^{-1}$.

The low legume content of these pastures was the main determinant factor of the values of $\mathrm{N}_{2}$ fixation per hectare.

L showed greater stability in cover and very similar nitrogenase activity when compared with WC, although with lower values during long periods of time.

MK compared with EP showed better compatibility with both legumes, tending to a greater legume cover and to higher $\mathrm{N}_{2}$ fixation in its mixtures.

The level of use had a generalized effect only during the first year, when HLU encouraged nitrogenase activity in autumn and winter originating similar trend in $\mathrm{N}_{2}$ fixation per hectare.

Acknowledgements: We wish to acknowledge Agron. Eng. Norma González and Daniel P. Miñon, Sr., Carlos Magazú and the National Institute of Agricultural Technology for the support given to this work.

\section{REFERENCES}

[1] Ball P.R., Crush J.R., Prospects for increasing symbiotic nitrogen fixation in temperate grasslands, in: Proc. 15th. Int. Grassld. Congr., Kyoto, Japan, 1985 , pp. 56-62.
[2] Bircham J.S., Hodgson J., The influence of sward conditions on rates of herbage growth and senescense in mixed swards under continuous grazing management, Grass Forage Sci. 38 (1983) 323-331.

[3] Bochetto R.M., Incorporation of technology in the Argentine livestock sector from an institutional perspective, $\mathrm{Ph}$. D. thesis, Michigan State University, USA, 1981.

[4] Bordeleau L.M., Prévost D., Nodulation and nitrogen fixation in extreme environments, Plant and Soil 161 (1994] 115-125.

[5] Brock J.L., Hoglund J.H., Fletcher R.H., Effects of grazing management on seasonal variation in nitrogen fixation, in: Proc. 14th Int. Grassld. Congr., Lexington, Kentucky, USA, 1983, pp. 339-341.

16] Cauhépé M.A., León R.J., Sala O., Soriano A., Pastizales naturales y pasturas cultivadas, dos sistemas complementarios y no opuestos, Rev. Fac. Agron. (U.B.A.) 3 (1) (1982) 1-11.

[7] Cochran W.G., Cox G.M., Diseños experimentales, Ed. Trillas, Mexico, 1971, pp. 342-344.

[8] Crush J.R., Tough H.J., Hydrogen evolution from white clover, N. Z. J. Agric. Res. 24 (1981) 365-370.

[9] Crush J.R., Cosgrove G.P., Brougham R.W., The effect of nitrogen fertilizer on clover nitrogen fixation in an intensively grazed Manawatu pasture, N. Z. J. Exp. Agric. 10 (1982) 395-399.

[10] Darwich N.A., Niveles de fósforo asimilable en los suelos Pampeanos, Instituto de Investigación Agraria (IDIA) (409-412) (1983) 1-5.

[11] Darwich N.A., González E.P., Persistencia de pasturas cultivadas: descripción del problema, in: Persistencia de pasturas mejoradas, Instituto Interamericano de Cooperación para la Agricultura (IICA) Cono Sur/ BID, Dialogo V, 1982, pp. 3-11.

[12] Escuder C.J., Santini F.J., Chifflet of Verde S., Assuero S., García Astrada A., Feeding value of two varieties of Festuca arundinacea (Schreb) under grazing conditions, Turrialba 42 (2) (1992) 238-242.

[13] Frame J., Problems of persistency of improved pastures, in: Persistencia de pasturas mejoradas, Instituto Interamericano de Cooperación para la Agricultura (IICA) Cono Sur/BID, Diálogo V, 1982.

[14] Godz P., Costamagna O., Cuenca del Salado o Pampa Deprimida, Instituto de Investigación Agraria (IDIA) (367-372) (1978) 69-78.

[15] Hoglund J.H., Brock J.L., Regulation of nitrogen fixation in a grazed pasture, N. Z. J. Agric. Res. 21 (1978) 73-82. 
[16] Hoglund J.H., Crush J.R., Brock J.L., Ball P.R., Carran R.A., Nitrogen fixation in pasture. XII. General discussion, N. Z. J. Exp. Agric. 7(1) (1979) 45-51.

[17] Lambert M.G., Nitrogen fixation during improvement of North Island hill country pastures, N. Z. J. Exp. Agric. 15 (1987) 267-270.

[18] Marriot C.A., Seasonal variation in white clover content and nitrogen fixing (acetylene reducing) activity in a cut upland sward, Grass Forage Sci. 43(3) (1988) 253-262.

[19] Masterson C.L., Murphy P.M., Application of the acetylene reduction technique to the study of nitrogen fixation by white clover in the field, in: Nutman, P.S. (Ed.), Symbiotic Nitrogen Fixation in Plants, Cambridge Univ. Press, Cambridge, 1976, pp. 229-316.

[20] Mazzanti A., González E.P., Arosteguy J.C., Evaluación de especies y variedades de forrajeras perennes. II. Crecimiento estacional de gramíneas perennes, Instituto Nacional de Tecnología Agropecuaria (INTA), EERA Balcarce, Argentina. Informe Anual de Actividades, Dpto. de Producción Animal, 1981, pp. IV10-IV-12.

[21] Mazzanti A., Darwich N.A., Cheppi C., Sarlangue H., Persistencia de pasturas cultivadas en zonas ganaderas de la Pcia. de Buenos Aires, Rev. Arg. Prod. Anim. 6, suppl. 1 (1986) 65.

[22] Mazzanti A., Montes L., Miñón D., Sarlangue H., Cheppi C., Utilización de Lotus tenuis en establecimientos ganaderos de la Pampa Deprimida: resultados de una encuesta, Rev. Arg. Prod. Anim. 8(4) (1988) 301-305.

[23] Miñón D.P., Refi R.O., Estabilidad de pasturas de Festuca arundinacea, Trifolium repens y Lotus tenuis bajo pastoreo contínuo, in: Diálogo XXXVIII: Evaluación de pasturas. Instituto, Interamericano de Cooperación para la Agricultura. Convenio IICA- BIDPROCISUR, 1993.

[24] Montes L., Lotus tenuis, Rev. Arg. Prod. Anim. 8 (5) (1988) 367-376.
[25] Murphy P.M., Photosyntate supply and nitrogen fixation in forage legumes, in: Proc. 14th. Int. Grassld. Congr. Lexington, Kentucky, USA, 1983, pp. 332-335.

[26] Refi R.O., Fijación de N de pasturas mixtas bajo dos intensidades de pastoreo, tesis M.Sc., Universidad Nacional de Mar del Plata, Fac. de Cs. Agrarias, Balcarce, Argentina, 1988, $182 \mathrm{pp}$.

[27] Refi R.O. Fijación asimbiótica de nitrogeno en dos cultivares de Festuca arundinacea Schreb bajo pastoreo continuo, Rev. Arg. Prod. Anim. 10 suppl. 1 (1990) 34-35.

[28] Sala O.E., Deregibus V.A., Schlichter T.M., Alippe H.A., Productivity dynamics of a native temperate grassland in Argentina, J. Range Manage. 34 (1981) $48-51$.

[29] Seresinhe T., Hartwig U.A., Kessler W., Nosberger J., Symbiotic nitrogen fixation of white clover in a mixed sward is not limited by height of repeated cutting, J. Agron. Crop Sci. 172 (1994) 279-288.

[30] Sinclair A.G., Hannagan R.B., Risk W.H., Evaluation of the acetylene-reduction assay of nitrogen fixation in pastures using small soil-core samples, N. Z. J. Agric. Res. 19 (1976) 451-458.

[31] Snaydon R.W., Micro-distribution of Trifolium repens $\mathrm{L}$. and its relation to soil factors, J. Ecol. 50 (1962) 133-143.

[32] Vessey J.K., Patriquin D.G., (1984) In situ nitrogen fixation by white clover in mixed swards in Nova Scotia, Can. J. Plant. Sci. 64 (3) (1984) 625-636.

[33] Videla C., Navarro C., González N., Miñón P., Darwich N., Escuder C., Estimaciones de las pérdidas de $\mathrm{N}$ por volatilización de $\mathrm{NH}_{3}$ en suelos de la Pampa Deprimida regados con orina de vacunos, Rev. Arg. Prod. Anim. 8, suppl. 1 (1988) 70-71.

[34] Winer B.J., Statistical Principles in Experimental Design, 2nd ed., McGraw-Hill. New York, 1971 